
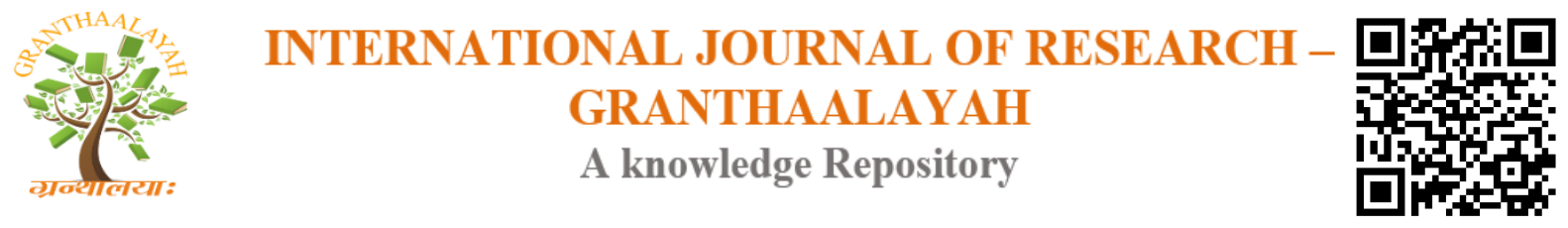

Social

\title{
HIPMI ORGANIZATION COMMUNICATION PATTERNS IN THE "HIPMI GOES TO SCHOOL" PROGRAM
}

\author{
Maria Fifi Yanti ${ }^{* 1}$, Henni Gusfa ${ }^{1}$ \\ ${ }^{1}$ Universitas Mercu Buana Jakarta, Indonesia
}

\begin{abstract}
The Indonesian Young Entrepreneurs Association (HIPMI) is an organization focused on developing entrepreneurship among Indonesia's young generation. This study intends to determine the communication patterns of HIPMI in implementing HIPMI Goes to School. This study aims to identify the flow of messages, barriers in the communication patterns of HIPMI through the HIPMI Goes to School program to foster the spirit of Social Entrepreneur in Indonesia's young generation. This research uses a case study method with a paradigm of the constructivist approach. Data obtained through in-depth interviews, literature study, observation, and internet searching. The data analysis techniques are carried out, through several stages, namely data reduction, data collection, data presentation, drawing conclusions, and evaluations. The results of the HIPMI organizational communication pattern research in implementing the HIPMI Goes to School program is the Triangle Pipe pattern. The obstacles in the organization's communication patterns in the HIPMI Goes to School activities are more on the busyness and time distribution of members who have other duties besides organizational tasks. The role in organizational communication patterns in HIPMI Goes to School activities is carried out following their respective responsibilities, both those that act as opinion leaders, gatekeepers, bridges, cosmopolites, liaison, and isolates.
\end{abstract}

Keywords: Central and Regional HIPMI; Organizational Communication Patterns; Social Entrepreneurs.

Cite This Article: Maria Fifi Yanti, and Henni Gusfa. (2020). "HIPMI ORGANIZATION COMMUNICATION PATTERNS IN THE "HIPMI GOES TO SCHOOL" PROGRAM." International Journal of Research - Granthaalayah, 8(4), 327-339. https://doi.org/10.29121/granthaalayah.v8.i4.2020.47.

\section{Introduction}

HIPMI is a non-partisan independent organization, which is not underfunded from any organization. HIPMI wants to bring its cadres to become national entrepreneurs who are tough but also become entrepreneurs who are nationally minded and have the people's conscience demands. HIPMI as an organization that positions itself as a service and promotes factors in future economic and business development in Indonesia following the vision and mission of the HIPMI strategy as 
its aim to encourage and participate in developing an entrepreneurial spirit among the younger generation.

In 1972 the young entrepreneurs of the time such as Drs. Abdul Latief, Ir. Siswono Yudo Husodo, Tengku Sj Ahrul, Datuk Hakim Thantawi, Badar Tando, Irawan Djajaatmadja, SH, Hari Sjamsudin Mangaan, Pontjo Sutowo, and Ir. Mahdi Diah agreed to establish an organization that aims to foster entrepreneurial value among Indonesian youth. Right on 10 June 1972 the Indonesian Young Entrepreneurs Association or often abbreviated to HIPMI was officially formed (Soesatyo, B. 1995).

The formation of HIPMI makes entrepreneurship discourse and movement increasingly discussed in various forums and media (Ramadhan, A. 2012: 1-8). Proven various methods of education and training are now increasingly active also offering these skills to be implemented by the wider community. Even in various Indonesian universities Entrepreneurship is used as one of the subjects taught to students. Even though educating someone for entrepreneurship is not an easy matter, especially in an era of very high social inequality and contrast and prosperity are exclusive goods. Therefore, the presence of Social Entrepreneurs is needed as part of the solution to social problems in the community. Therefore, since the establishment of HIPMI, it has the aim to be a place to educate young Indonesian entrepreneurs.

From year to year, the number of HIPMI membership continues to grow, which has now reached more than 40,000 thousand Members throughout Indonesia. Through the Education and Training process and the gradual regeneration needed qualified cadres to move HIPMI. Besides, the HIPMI regeneration process that developed to continue to encourage and foster an entrepreneurial spirit, in 2011 BPP HIPMI formed the PT HIPMI Autonomous Agency as a forum that serves to realize the implementation of HIPMI programs in Higher Education institutions to serve and encourage economic and business development in Indonesia can provide maximum benefits for both members and the community (Tiffani, R., \& Siswati, S. 2017).

It is not enough to stop there, HIPMI in the management of the 2015-2018 period under the leadership of Bahlil Lahadalia, seeing the phenomenon of the number of entrepreneurs from the younger generation has not increased, especially among students, HIPMI again initiated a superior program to encourage and develop entrepreneurial interest through the "HIPMI Goes To School "which was launched coincided with the opening of the 2015-2018 HIPMI National Work Meeting (Rakernas) on 27 March 2017 which was directly opened by the President of the Republic of Indonesia, Mr. Joko Widodo.

Based on these conditions, in this study, researchers are interested in examining "How the HIPMI BPP Communication Patterns on the" HIPMI Goes to School "program to develop the spirit of sociopreneurship in schools. Therefore a study was conducted on the Central and Regional HIPMI Communication Pattern on the "HIPMI Goes to School" program to develop the entrepreneurial spirit of entrepreneurship in schools. 


\section{Research Methodology}

The research method is a scientific way to get data with specific purposes and uses (Sugiyono, 2014: 2). Based on the problems that have been formulated previously, this research uses descriptive methods through a qualitative approach. According to Sugiyono (2014: 9), qualitative research methods are research methods based on the philosophy of post-positivism, used to examine natural conditions of objects, where researchers are as key instruments, data collection techniques are carried out by triangulation (combined), data analysis is inductive/qualitative, and qualitative research results emphasize more meaning than generalization. According to Hasan (2002: 22), the descriptive method is research that studies problems, procedures that occur in society and certain situations that include relationships, activities, attitudes, views, and processes that are taking place and check the causes of a phenomenon. Data collection techniques in this study used in-depth interviews, direct observation, and documentation.

The data analysis technique used in this study is the Miles and Huberman model in which the qualitative data analysis process is divided into three stages as follows: 1). Data reduction is a field report in the form of a description to be reduced, to sort out the main points, and to focus on what is important and to discard what is not needed. Data reduction takes place continuously throughout the research process. 2). Presentation of data (data display) Presentation of data in this study in the form of tables, descriptions and descriptive text is an explanation to have meaning that can be understood by others. 3). Conclusion (verification) the end of the research is to make conclusions.

\section{Discussion}

\section{HIPMI Journey at a Glance}

The Indonesian Young Entrepreneurs Association (HIPMI) was established on June 10, 1972. The founding of this organization was based on a passion to foster entrepreneurship among young people. The establishment of HIPMI was motivated by social factors among Indonesian young people who lived in 1970. At that time, very few young people wanted to become entrepreneurs. The profession that was loved by the younger generation at that time was to become a technocrat or to become an employee of the government bureaucracy, beyond that some chose the path to become employees on a national or international scale. Therefore, the founders of HIPMI consisting of Drs. Abdul Lati ef, Ir. Siswono Yudo Husodo, Teng ku Sjahrul, Datuk Hakim Thantawi, Badar Tando, Irawan Djajaatmadja, SH, Hari Sjamsudin Mangaan, Pontjo Sutowo, and Ir. Mahdi Diah agreed to establish an association called the Indonesian Young Entrepreneurs Association (HIPMI).

Within 47 years, the Indonesian Young Entrepreneurs Association continues to grow. In 2019 all HIPMI members numbered more than 40,000 and more than 200,000 former members. In its journey, HIPMI has a big contribution in increasing the Indonesian economy. many public figures and leaders who have succeeded in inspiring the younger generation of Indonesian inspiring leaders born from this organization, such as Aburizal Bakrie, Abdul Latief, MS. Hidayat, Muhammad Lutfi, Sandiaga S. Uno, Erwin Aksa and most recently Raja Sapta Oktohari. 
As the goal from the beginning establishment, HIPMI had the aim to produce a cadre of young Indonesian entrepreneurs who were able to compete. Then the Board of BPP HIPMI 2015-2019 Service Period has the following programs: 1). HIPMI Goes to Campus, this program aims to strengthen the HIPMI regeneration base through strengthening PT HIPMI and implementing tiered Education and Training. 2). HIPMI Goes to School, this program was implemented to foster entrepreneurial interest and a spirit of patriotism and nationalism among "grassroots" students. 3 ). Business Talk, this program is in collaboration with stakeholders and share mass media and associations 4). Foreign Trade Mission, this program aims to open market access for HIPMI members, provide reference material for knowledge about the world of global business; and expand networking. The program that will be discussed in this research is BPP HIPMI's second flagship program; HIPMI Goes to School, this program is interesting to study because the object of the program is students, so they know the factors that make this event a success and also the obstacles they will experience can be input for all groups, including government, academics, and other professionals.

\section{Organizational Communication Patterns}

Organizational communication can be defined as the display and interpretation of messages among communication units that are part of a particular organization (Pace \& Faules, 2015: 31-33). An organization consists of communication units in hierarchical correlations between one another and functions in an environment.

In the traditional sense (functionalist and objective) organizational communication tends to emphasize the message-handling activities contained in an "organizational boundary". While organizational communication in an interpretive perspective (subjective) is the process of creating meaning for interactions that constitute the organization. Organizational communication is the "organizing behavior" that occurs in how they are involved in the process of dealing and giving meaning to what is happening.

According to Miller (Le Breton-Miller, I., \& Miller, D. 2015: 397-415), organizational communication can be done in various ways, but there is an agreement that the organization involves social collectivity (a group of people) in which all activities are coordinated to achieve a goal. Organizational communication is divided into two dimensions, namely vertical and horizontal communication, vertical communication is the communication from top to bottom or from the bottom up as communication from the leadership of the organization to members and or vice versa (two-way traffic communication).

In vertical communication, leaders provide instructions, guides, information, and explanations to their members. Then the members provide reports, suggestions, input, etc. to the leadership. This two-way communication is very important in an organization because if it is only one direction, for example from the leader to its members, then the wheels of the organization will not run well. Smooth, open and complementary vertical communication is the attitude of the leadership of a democratic organization. The BPP HIPMI management needs to know the reports, responses or suggestions of the management so that a decision or policy can be taken to achieve the stated goals. 


\section{Information Flow}

The information does not flow literally. Information itself is not moving including the delivery of a message, interpretation of the delivery and the creation of other delivery. The creation, delivery, and interpretation of messages are a process that distributes messages throughout the organization. The concept of the process implies that events and relationships move and change continuously, that events and correlations are dynamic. A dynamic relation or event involves energy and action. So, what we call information flow in an organization is a dynamic process; it is in this process that messages are constantly and continuously created, displayed and interpreted. This process continues and changes constantly meaning that organizational communication is not something that happens then stops. Communication happens all the time.

Guetzkow (1965) in (Pace \& Faules, 2015: 171) states that the flow of information in an organization can occur in three ways: simultaneous, sequential or a combination of these two ways. Simultaneous dissemination of messages from organizational communication takes place from person to person, or in conjunction, involving only the source of the message and the recipient who interprets the message as the final destination.

\section{Information Flow Patterns}

Katz and Kahn (1966) in (Pace \& Faules, 2015: 174) suggest that a regular pattern or state of affairs requires that communication between the members of the system is limited. Burgess (1969) states that the peculiar character of communication in organizations is that "messages flow so highly that we can talk about networks or communication structures" (Burgess, R. L. 1969: 137159). Then Burgess added that formal organizations control the structure of communication by using certain means such as showing authority and work relationships, assigning offices and special communication functions. The role in organizational communication patterns in HIPMI Goes to School activities is carried out following their respective responsibilities, both those that act as opinion leaders, gatekeepers, bridges, cosmopolites, liaison, and isolates.

\section{Information Flow Direction}

In organizational communication we talk about information that moves formally from someone whose authority is higher to someone else whose authority is lower - downward communication; information that moves from a position of inferior authority to a person of a higher authority Communication to the Top is both formed vertical communication.

Downward communication means that information flows from high-authority positions to those with low authority. There are five types of information that are usually communicated from superiors to subordinates according to (Katz \& Kahn, 1996) in (Pace \& Faules, 2015: 185): (1) Information on how to do work, (2) Information on the rationale for doing work, (3) information about organizational policies and practices, (4) information about employee performance, and (5) information to develop a sense of mission (sense of mission).

Communication to the Top means that information flows from a lower level (subordinate) to a higher level. Planty and Machaver (1952) in (Pace \& Faules, 2015: 193) have principles as a guideline for Upward communication programs namely: (1) An effective communication program upwards must be planned, (2) An effective upward communication program takes place on an ongoing basis, (3) Effective upward communication programs emphasize sensitivity and 
acceptance in the entry of ideas from a lower level, (4) Effective upward communication programs using routine channels, (5) Effective upward communication programs include listening effectively objective, (6) Effective top-up communication program includes actions to respond to problems and (7) Effective top-up communication program uses various media and methods to improve information flow.

Information disseminated among members of an organization that occupies positions of the same level of authority is called Horizontal Communication. Horizontal communication consists of conveying information among colleagues in the same work unit. Work units include individuals who are placed at the same level of authority in the organization and have the same boss. The purpose of horizontal communication has six reasons namely: (1) To coordinate work assignments, (2) Sharing information about plans and activities, (3) To solve problems, (4) To gain mutual understanding, (5) To reconcile, negotiate, mediate differences, (6) To foster interpersonal support.

\section{HIPMI Goes to School Program}

In this case, the researcher gets the results and most of the answers are almost the same in every answer given by the informant. So according to the theory chosen by researchers that one of the big challenges in organizational communication is how to convey information to all parts of the organization that is carried out with various information flows. As with the HIPMI Goes to School program initiated by the HIPMI Central Board and disseminating to Banom HIPMI PT, BPD HIPM, and BPC HIPMI at acceptable levels. Thus it can be concluded the process of delivering the information flow of the HIPMI Goes to School program is carried out simultaneously and sequentially. As mentioned in the flow of information in an organization is a dynamic process, in this process messages are constantly being created, displayed and interpreted.

The HIPMI Goes to School Program delivered by BPP HIPMI simultaneously at the time the program was first declared through the HIPMI National Working Meeting (Rakernas) meeting that wanted more than one person. Such as Banom HIPMI PT, BPD HIPMI, BPC HIPMI, and HIPMI members. From the results of the research, the HIPMI Goes to School program also carried out sequential program information submission namely BPP HIPMI conveying to BPD HIPMI and BPC HIPMI. As stated in the pattern of information sequential distribution of messages, the dissemination of information takes place in irregular time, so the information arrives at different places and at different times. As in public lecture activities, seminars and workshops attended by BPP HIPMI or Banom HIPMI PT BPP HIPMI in their respective regions.

From the whole BPP, BPD and BPC who were informants stated that the HIPMI Goes to School program was very appropriate and good for middle school students and at the same level to change the mindset of students from the civil service profession to become entrepreneurs. HIPMI Goes to School as one of the spirit of entrepreneurship virus from an early age and included in the curriculum or subjects whose orientation is how to build independence and the spirit of entrepreneurship and create their income or even be able to create the skills they have. It is expected, when the finished school can continue their studies while designing a business or an entrepreneurial object to support their lecture activities and it is expected that after that, from the small experiences more strengthened with the stock of knowledge possessed from the school can add value to the business being cultivated. 
However, from the various statements, different reasons are depending on each region such as BPD and BPC HIPMI in responding to the communication pattern of program delivery beginning with schools and coordinating with BPD and BPC HIPMI as well as opening communication to the Office of Cooperatives and SMEs so that relevant parties provide follow-up for the local BPD to provide access to capital. This was also stated by the pattern of communication carried out by BPP HIPMI or delegation from the Central Board to Banom HIPMI PT to deliver the program with a strategy to introduce HIPMI and entrepreneurial programs. At the same time by establishing partners from several CSR companies, they assist and indoctrinate students to choose to become entrepreneurs. As intended in the concept of communication a pattern is a system consisting of components related to one another to achieve goals. This means that the pattern of communication carried out by BPP HIPMI in the HIPMI Goes to School program is about how to communicate someone in an organizational context which includes the content of the communication, the direction of communication flow ways or channels of communication and communication style. Communication plays an important role in a system, especially regarding interdependence. Interdependence indicates that the components or units are interdependent of a system. A change in a component brings changes to every other component. Likewise, the HIPMI Goes to School program initiated by BPP HIPMI in its implementation there are many obstacles encountered such as the results of research from BPD and BPC HIPMI that the implementation of the program there are obstacles in each program that requires mobilization and costs (costs) such as institutional infrastructure because this program is new designed which started from the existence of HIPMI goes to school. Therefore, because HIPMI has not made regulations internally so far regarding the HIPMI institutional program goes to school, Campus, and Islamic Boarding School. Another statement added that the obstacle of the Goes to School HIPMI Program was because it was only limited to socialization activities should also be formed as the basis of PT HIPMI as a semiautonomous institution or a place to gather so that it could be well coordinated.

\section{BPP HIPMI Communication Patterns in the Goes to School HIPMI Program Using the Triangle Pipe Model Approach}

The term communication pattern is commonly referred to as a model but the intention is the same, namely a system consisting of various components that are related to each other to achieve educational goals in society. A pattern is a form or model (more abstract, a set of rules) that is commonly used to make and to produce something or a part of something, especially if it is sufficiently reached for a type of archetype that can be shown or seen. Communication patterns are processes that are designed to represent reality. the linkages of the elements covered and their continuity, to facilitate systematic and logical thinking.

The pattern of communication in question is a general description of how to communicate someone in the organizational context which includes the content of the communication, the direction of communication flow, the mode or channel of communication (the mode or channel of communication) and the style communication (style of communication). If referring to the communication patterns presented by Widjaja, the communication pattern of the HIPMI organization in implementing the HIPMI Goes to School program is the Triangle Pipe pattern. Triangle Pipe communication pattern is a communication model that involves three elements, in this case, the Central Management (BPP HIPMI), Regional Management (BPD HIPMI) and Branch Management (BPC HIPMI) where all members and management communicate with each 
other. This communication has a reciprocal reaction from all interlocutors. Which if the diagram is made as follows:

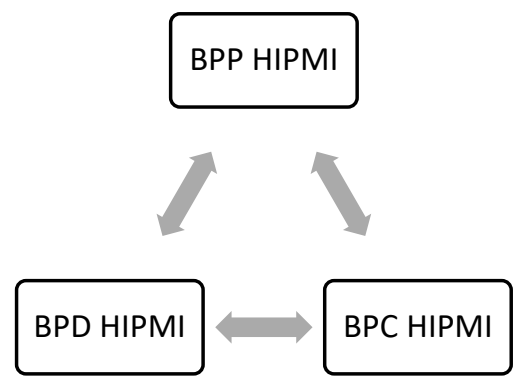

Figure 1: Triangle Pipe Communication Pattern applied at HIPMI

HIPMI as a cadre organization in the HIPMI organizational structure is at the central and regional levels. HIPMI stipulates that there is a Central Management Agency domiciled in the National Capital, Regional Management Agency domiciled in the Provincial Capital and Branch Management Agency domiciled in the Regency / City Capital. Until now HIPMI has 34 Provinces and has 507 Branch Management Agencies. The message that becomes information in the communication process of the HIPMI BPP Management, HIPMI BPD Management and also HIPMI BPC Management is the division of tasks and authority, programs and strategies in the success of all HIPMI programs. The character of the leader or chairperson shown by the BPP HIPMI chairman or the chairperson of the BPD and BPC shows a model of family and friendship approaches. With this kind of communication model, there is smooth communication between the chairman and the members and there is no limit.

In terms of organizational structure, HIPMI is a formal organization that has authority, such as the Central Management Agency, the authority above the Regional Management Agency and the Regional Management Agency is the authority over the Branch Management Agency. Because this hierarchy is applied for operational matters, for strategic matters the coordination is carried out in the Consultative Institution. Consultative institutions intended in HIPMI that can accommodate and initiate discussions within the framework of the policy direction of the organization.

HIPMI Autonomous Board of higher education as an organizational tool formed by the Central / Regional / Branch Management Board to carry out special activities/specialties, interests/talents and is responsible to the Management Board according to its level. The main program when it was formed began with the HIPMI Goes to Campus program aimed at being a driving force in supporting the recruitment and regeneration process of HIPMI entrepreneurs at the campus level, intending to create one million people in supporting and developing entrepreneurial interests throughout Indonesia. 


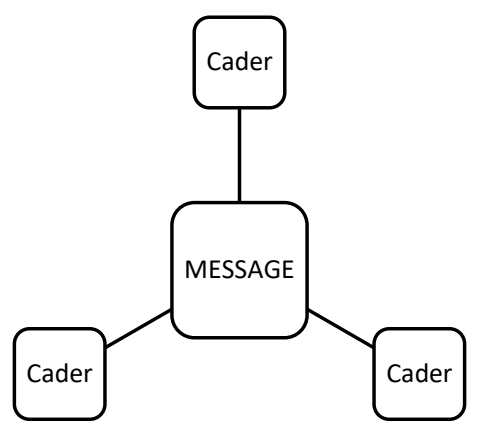

Figure 2: Communication patterns and delivery of HIPMI cadre messages

This study found the fact that the communication model used at HIPMI is the Triangle Pipe communication model which in the process distributes clear information as Weiss's theory bases the clarity of information on the following matters: 1). Leader Character, 2). Channels and delivery methods used. In the process of communication and organization in HIPMI put forward the principle of "Family and Friendship"; through this principle and slogan HIPMI administrators have emotional closeness and social capital that is very good for the success of all its programs.

Communication between the management and cadres of HIPMI is in the form of verbal and nonverbal communication. For indirect communication, HIPMI administrators and cadres use social media and are accustomed to communicating and coordinating with each other on WhatsApp applications, email, and telegram.

HIPMI Goes to school is one of the HIPMI central policy activities or programs for the 2015-2018 periods which are carried out throughout the internal hierarchy of the organization, especially the HIPMI Autonomous Body of PT, the Regional Management Board, and the HIPMI Branch Management Board throughout Indonesia. In the process of planning to the evaluation of the HIPMI Goes to school program, the BPP HIPMI administrators used Weick's approach to organizing and communicating. This is reflected in the pattern of communication and organizing that is oriented towards programs and organizational agreements.

As Weick (1979) in (Pace \& Faules, 2015: 78) defines organizational communication as a grammatically agreed agreement to reduce ambiguity by using thoughtful behaviors that are interlocked. Consensual validation means that the reality of the organization arises from the experiences that have been endorsed and validated by others. These experiences are shared with others through symbol systems. (Kharisma, V. D., et all. 2020: 1-20).

Grammar means several rules, conventions, and organizational practices. These conventions help people carry out their duties and provide a basis for interpreting what has been done.

The Board of BPP HIPMI is always present in every activity process. Of course, this was done so that the HIPMI Goes to school program was successfully implemented. The pattern of communication between the central board and regional administrators is two-way communication or in the Weick concept known as double interact (Pace \& Faules, 2015: 81). This means that in communication between the central executive and regional administrators are communication where A (central executive) communicates with B (regional executive), B responds to A, and A 
makes some adjustments or responds to B. This unique type of communication activity forms the basis organizing. This linked communication behavior makes the organization able to process information.

In organizing the HIPMI Goes to school BPP HIPMI program by conducting organizational planning and policies through organizational structures that are determined by interlocking behaviors. The HIPMI Goes to School program is a joint consensus endorsed by consensus to reduce ambiguity by using wise behaviors. HIPMI Goes to School also has a double interaction, in this case, BPP HIPMI communicates with BPD HIPMI, BPD HIPMI responds to BPP HIPMI and BPP makes adjustments or responds to BPD HIPMI. So, both of them can process information. In the process of organizing stages, BPP HIPMI uses organizing stages that are intertwined in sequence. The enactment process simply means that members of the organization re-create their environment by defining and negotiating specific meanings for an event. Members of the organization, in this case, are inseparable from the influence of the environment. This is because Weick believes that organizations are attached to the environment. The environment here does not only consist of the physical environment, or does not only refer to the environment of the organization and other institutions associated with the organization. Furthermore, Weick refers to the environment as an information environment where some activities and experiences inspire meaningful by organizational participants.

Furthermore, the selection process involves the imposition of various structures when there is obscurity to reduce the obscurity. Selection in organizing is an effort to choose how to deal with people and situations so that a sense of comfort will be achieved and unintended consequences can be prevented and resolved properly. Returning to the example above, the individual who had entered the meeting room and when he entered everyone in the room laughed, going through the selection process.

Meanwhile, the retention process is a process in which when an action that has been selected turns out to be able to overcome the uncertainty of the situation at hand, then the action will then be used again to deal with the same situation in the future. This storage process can be in the form of being made into formal rules or procedures in the organization, or it can be simply stored in the minds of each member of the communication (Payiz Zawahir Muntaha, et all. 2019: 123-132)

In the implementation of the Goes to School HIPMI program, the National Board that is affiliated with BPP HIPMI communicates downward in delivering organizational policies to all organizational instruments namely the Autonomous Body, BPD, and BPC HIPMI at the same level throughout Indonesia to be implemented in every school in the region. This organizational device must have good communication skills so that the approach taken and the messages conveyed can be arranged effectively and systematically. Communication is a process that aims to influence a person's attitudes, opinions and behavior both verbally and nonverbally. The process itself is every symptom or phenomenon that shows a continuous change in the context of the time, or every implementation or treatment continuously (Soemirat, et al, 2004: 2-23).

The program delivered by the HIPMI Center seeks to aim to change the mindset, knowledge about entrepreneurship and invite students and teachers to develop soft skills in schools as pioneers of social entrepreneurship (sociopreneurship) that have a spirit of patriotism, integrity, resilience, and 
nationalism. Every organization that is filled with human resources, some who have a role as a leader and most others play a role as a member. Everyone involved in the organization will communicate. There is no organization without communication because communication is an integral part of the organization. Thus, the pattern of communication in every organization has a central and important role in obtaining effective results.

Students in senior high schools participating in the HIPMI Goes to School activity welcomed the program enthusiastically and were very enthusiastic about participating in the activity. This can be seen from the implementation of the HIPMI Goes to School activities which were participated by more than two hundred people in one activity. The HIPMI Goes to School program is conducted such as a motivational training program, success stories, educational counseling that is educational and also provides access to capital. Besides, in this program, the activity also uses the media as a means to motivate and develop the entrepreneurial spirit of students. The use of active media is expected to be one of the supports to improve the development of social entrepreneurship (Sociopreneurship) in schools. The media used in the socialization of the HIPMI Goes to School program to students is online media and offline media. Inactive online media HIPMI media such as Facebook, Twitter and hipmi.net are used.

In Indonesia, efforts to instill the spirit and spirit of entrepreneurship in higher education continue to be encouraged and enhanced, of course, with various methods and strategies that make students interested in entrepreneurship (DIKTI, 2012). It is also no less important that entrepreneurship is carried out from elementary school, high school, to college. Filion and Dolabela (2007: 13) highlight the importance of learning entrepreneurship since elementary school.

The agenda in Indonesia is to prepare the young generation who are currently sitting in school to be ready to become entrepreneurs. So, there is no need to wait until there is unemployment then open entrepreneur courses. an understanding that is more than the wise saying "umbrella ready before it rains", prepare a house that is good, strong, and can be used by everyone to not only shelter but also live comfortably in it in the bright and rainy season.

\section{Inhibiting Organizational Communication Factors in BPP HIPMI in Implementing HIPMI Activities Goes to School}

In carrying out communication and implementing organizational work programs sometimes the results achieved are not continuous as expected, in other words, communication is ineffective and or does not reach the target well. In its implementation, communication between management, either fellow BPP HIPMI central managers or regional administrators can be hampered by several factors, such as between the leadership and management and members do not understand the communication process that they do, there are differences in perception in understanding a problem about the tasks and responsibilities which is already a part of every individual. Apart from that, the existence and distrust of the recipient of information towards the information giver, and also the giver of information that is not following reality become one of the factors as well.

In the process of implementing the HIPMI Goes to School program, the main obstacle in communication and implementation of activities is the personal busyness of each board, each of which also has a company and activities that sometimes cannot be left behind. Nevertheless, the division of tasks and the delegation of authority made the activities successful. The existence of a 
leader and coordinator in each event can make the committee solid and able to complete the tasks assigned. This is consistent with the research conducted by Ilyas Lampe. The results of the study showed that community leaders (actors), coordinators or chairmen were able to build solidity and shared narratives that unite different ethnicities (2018: 860-873). Apart from that, in communicating and organizing commitments to tasks and responsibilities as well as time management capabilities become one of the main factors and become things taught in HIPMI as an organization.

\section{Conclusion}

HIPMI as a cadre organization in the HIPMI organizational structure is at the central and regional levels. HIPMI Goes to school is one of the HIPMI central policy activities or programs for the 2015-2018 periods which are carried out throughout the internal hierarchy of the organization, especially the HIPMI Autonomous Body of PT, the Regional Management Board, and the HIPMI Branch Management Board throughout Indonesia. In the process of planning to the evaluation of the HIPMI Goes to school program, the BPP HIPMI administrators used Weick's approach to organizing and communicating. If referring to the communication patterns presented by Widjaja, the communication patterns of the HIPMI organization in implementing the HIPMI Goes to School program are stellar communication patterns. The results of the study showed that the flow of organizational communication messages carried out by the HIPMI organization in the HIPMI Goes to School activities had been going as expected. The obstacles in the organization's communication patterns in the HIPMI Goes to School activities are more on the busyness and time distribution of members who have other duties besides organizational tasks. The role in organizational communication patterns in HIPMI Goes to School activities is carried out following their respective responsibilities, both those that act as opinion leaders, gatekeepers, bridges, cosmopolites, liaison, and isolates.

\section{References}

[1] Ardianto, E., \& Soemirat, S. (2004). Dasar-dasar public relations. Cetakan Ketiga. Bandung: Remaja Rosdakarya.

[2] Burgess, R. L. (1969). Communication Networks and Behavioral Consequences!. Human Relations, 22(2), 137-159.

[3] Filion, L. J., \& Dolabela, F. (2007). The making of a revolution in Brazil: The introduction of entrepreneurial pedagogy in the early stages of education. Chapters.

[4] Guetzkow, H., \& March, J. G. (1965). Handbook of organizations.

[5] Hasan, M. Iqbal. "Pokok-pokok Materi Metode Penelitian dan Amplikasinya Cet 1." Jakarta: Ghalia Indonesia (2002).

[6] Kharisma, V. D., Samputra, P. L., \& Muntaha, P. Z. (2020). ANALISIS DAMPAK KEBIJAKAN ALOKASI DANA OTONOMI KHUSUS BIDANG PENDIDIKAN DAN KESEHATAN TERHADAP INDEKS PEMBANGUNAN MANUSIA DI PROVINSI PAPUA. Journal Publicuho, 3(1), 1-20.

[7] Lampe, I. (2018). Pola Komunikasi Gerakan Sosial Komunitas Sekitar Tambang Migas Tiaka: Refleksi Identitas Etnik Lokal. Jurnal Aspikom, 3(5), 860-873.

[8] Le Breton-Miller, I., \& Miller, D. (2015). The paradox of resource vulnerability: Considerations for organizational curatorship. Strategic management journal, 36(3), 397-415.

[9] Lexy, J. Moleong, 2011, metodologi penelitian Kualitatif. PT Remaja Rosdakarya, Bandung. 
[10] Lih-Brody, L., Powell, S. R., Collier, K. P., Reddy, G. M., Cerchia, R., Kahn, E., ... \& Fisher, S. E. (1996). Increased oxidative stress and decreased antioxidant defenses in mucosa of inflammatory bowel disease. Digestive diseases and sciences, 41(10), 2078-2086.

[11] Lih-Brody, L., Powell, S. R., Collier, K. P., Reddy, G. M., Cerchia, R., Kahn, E., ... \& Fisher, S. E. (1996). Increased oxidative stress and decreased antioxidant defenses in mucosa of inflammatory bowel disease. Digestive diseases and sciences, 41(10), 2078-2086.

[12] Nurhamzah, N., Priatna, T., Hasanah, A., \& Muntaha, P. Z. (2018, October). Inheritance modelbased character values of local wisdom. In International Conference on Islamic Education (ICIE 2018). Atlantis Press.

[13] Pace, R. W., Faules, D. F., \& Mulyana, D. (2000). Komunikasi organisasi: strategi meningkatkan kinerja perusahaan. PT Remaja Rosdakarya.

[14] Payiz Zawahir Muntaha, Virgie Delawillia Kharisma, and Margareta Hanita. (2019). "INDONESIAN GOVERNMENT APPROACHES AND POLICIES FOR RESOLVING PAPUA CONFLICTS." International Journal of Research - Granthaalayah, 7(12), 123-132

[15] Planty, E., \& Machaver, W. (1952). Upward communications: A project in executive development. Personnel, 28(4), 304-318.

[16] Priatna, T., Hamzah, N., \& Zawahir Muntaha, P. (2018). Learning Model of Islamic Education in National Perspective School: Case Study in Integrated High School Krida Nusantara, West Java, Indonesia.

[17] Ramadhan, A. (2012). Politik ekonomi generasi muda implementasi kebijakan gerakan kewirausahaan nasional di Jawa Timur. Jurnal Politik Muda, 2(1), 1-8.

[18] Setyawati, N. K. D., Prijowidodo, G., \& Inggrit, I. (2018). Pola Komunikasi Organisasi PDI Perjuangan dalam Proses Kaderisasi di DPC Kabupaten Sidoarjo. Scriptura, 8(1), 30-40.

[19] Soesatyo, B. (1995). HIPMI: gerakan \& pemikiran. Pustaka Aksara.

[20] Sugiyono, P. D. (2014). Metode Penelitian Kuantitatif Kualitatif dan R\&D. Indonesia: ALFABETA.

[21] Tiffani, R., \& Siswati, S. (2017). Hubungan antara Efikasi Diri Berwirausaha dengan Perilaku Inovatif Pada Anggota Himpunan Pengusaha Muda Inodnesia (HIPMI) Perguruan Tinggi Semarang (Doctoral dissertation, Undip).

*Corresponding author.

E-mail address: fifi.hipmi12@gmail.com 